\section{The relationship analysis of compliance consuming iron tablet with incidence of anemia on pregnant mothers in third trimester at the co-endemic areas of Bengkulu City, Indonesia}

\author{
Zurviani Oktania Wardhani, ${ }^{1}$ \\ Ahmad Fickry Faisya, ${ }^{1}$ Misnaniarti, ${ }^{2}$ \\ Ikhsan Ikhsan ${ }^{3}$ \\ ${ }^{1}$ Public Health Faculty, Sriwijaya \\ University; ${ }^{2}$ Health Policy \\ Administration, Public Health Faculty, \\ Sriwijaya University; ${ }^{3}$ Nursing \\ Department of Mathematics and \\ Natural Sciences Faculty, Bengkulu \\ University, Indonesia
}

\begin{abstract}
In developing countries generally, the incidence of anemia in pregnancy is still a major public health problem. This study aims to analyze the compliance of consuming Iron tablets with the incidence of anemia on pregnant mothers in the third trimester at Bengkulu city. This study used cross-sectional design, samples were third trimester pregnant mothers taken by purposive sampling as many as 106 pregnant mothers. Data analysis was carried out by using chi-square and binary logistic regression test. The results of Chi-square test on factors related to compliance, it was obtained that consumption of iron tablets, ANC services, ANC visits, and availability of iron tablets were significantly relationship with the incidence of anemia ( $p$-value $<0.05)$. While the results of binary logistic test stated that the availability of iron tablets was the most dominant influence on the incidence of anemia ( $p$ value $=0.023)$, OR 13.95 (95\%CI: 1.438 135.459). It is expected that the local government must pay more attention to plan the need of Iron tablets based on the estimation number of pregnant mothers.
\end{abstract}

\section{Introduction}

Anemia prevalence is still very high throughout the world, estimated by $58 \%$ of pregnant mothers in developing countries having anemia, and about $50 \%$ of them suffer from iron deficiency anemia. ${ }^{1,2}$ Anemia is one of the indirect causes of maternal mortality when giving birth to the worst impact for the baby born from a mother who suffer of anemia during her pregnancy will have an impact the obstructed of growth and development.

During 2013 an estimated 90,000 deaths were caused by anemia. ${ }^{3}$ Maternal mortality was reported as many as 115,000 maternal deaths each year due to iron deficiency anemia and Asia was the second highest mortality due to iron deficiency anemia. Approximately 3.6 million babies die during the neonatal period. More than a third of child deaths were estimated to be due to lack on nutrition intake of maternal during pregnancy. ${ }^{4}$

During pregnancy there is an increased need for iron in the body needed for enzymatic and metabolic reactions. If iron needs are not met, iron deficiency anemia can occur. In addition, the presence of infectious diseases in pregnancy can also aggravate the condition of pregnant mother, because it can reduce iron absorption. Malaria parasite infection is easy occuring on pregnant mother due to changes in the immune system and increased hormones during pregnancy. Malaria is an infectious disease that affects the health of pregnant mother which can lead to anemia, cerebral malaria, pulmonary edema, kidney failure and can even cause death. Malaria on pregnant mother can cause abortion, premature labor, low birth weight, and fetal death. There were $50 \%$ of pregnant mother infected with malaria in addition to have anemia also have low serum Iron levels. Serum Iron reduction indicated that there was a decreasing in iron reserves in the body. ${ }^{5}$

Iron supplements given early in pregnancy have an impact on increasing levels of hemoglobin and ferritin during pregnancy and increasing iron supply until the puerperium. Recommendation that every pregnant woman for 6 months to consume iron tablets $60 \mathrm{mg}$ and folic acid $400 \mathrm{mg}$ and continue the dose of Iron to 120 $\mathrm{mg}$ after giving birth to prevent the occurance anemia during childbirth. ${ }^{3}$

The providing standard on iron tablets was integrated in antenatal care services as an effort to prevent maternal death. ${ }^{6}$ Measuring the compliance of consuming iron tablets is very important, because iron tablets when taken regularly for long periods can be felt the advantages. Many factors inhibit the maternal adherence in consuming iron tablets. ${ }^{7}$

Iron requirements during pregnancy in malaria endemic areas increased from normal needs, this was because between malaria parasites and pregnancy both require iron. ${ }^{5}$ Bengkulu Province was the highest malaria endemic area on the Sumatra island with the highest prevalence of malaria 9,3\%
Correspondence: Zurviani Oktania Wardhani, Master Students of Public Health Faculty Sriwijaya University, Jl. Raya PalembangPrabumulih Km. 32 Indralaya, OI, Sumatera Selatan 30662, Indonesia.

Tel: +62711580169, Fax: +62711580644.

Email: zurvianioktania@gmail.com.

Key words: compliance, availability of Iron tablets, anemia.

Contributions: the authors contributed equally.

Conflict of interests: the authors declare no potential conflict of interests.

Funding: competitive funds on 2018 Fiscal Year of Sriwijaya University.

Clinical trials: the study is not involved any clinical trials.

Conference presentation: part of this paper was presented at the $3^{\text {rd }}$ International Symposium of Public Health, 2018 October 31- November 1, Universitas Airlangga, Surabaya, Indonesia.

Acknowledgments: Researchers would like to thank to the funding of research through competitive funds on 2018 Fiscal Year of Sriwijaya University, as well as all related parties who have helped during the process of this thesis research, to the Head of Health Office of Bengkulu City, Head of M. Yunus Hospital., Head of the Provincial Health Office Bengkulu, lecturers of Bengkulu University, Poltekkes Kemenkes Bengkulu and head of Public Health Center and staff of the KIA program.

Received for publication: 28 July 2019.

Revision received: 9 September 2019.

Accepted for publication: 15 October 2019.

This work is licensed under a Creative Commons Attribution NonCommercial 4.0 License (CC BY-NC 4.0).

CC Copyright: the Author(s), 2019

Licensee PAGEPress, Italy

Journal of Public Health in Africa 2019; 10(s1):1202 doi:10.4081/jphia.2019.1202

due to vivax plasmodium infection. ${ }^{8}$ Based on Bengkulu's health profile data there was an increase in low birth weight cases from 40 cases (2014) and 81 cases (2015), and it was also obtained that the third reduction in iron tablet coverage was $86.6 \%$ (2016). This needs to get the attention of management of maternal and child health programs to see how much the level of compliance of pregnant mother to consume iron tablets regularly and what factors influence the anemia incidence at co-endemic area of Bengkulu City. 
Prevalence of anemia as a public health problem was classified into three categories: severe problems $(>40 \%)$, moderate (20.0-39.9\%), mild (5.0-19.9\%) and normal $(\leq 4.9 \%)$. Anemia in pregnancy was assessed by hemoglobin levels $<11 \mathrm{~g} / \mathrm{dL}$ in the first and third trimesters, or $<10 \mathrm{~g} / \mathrm{dL}$ in the second trimester. The increasing acceleration of plasma volume which disproportionate to the red blood cells volume occures on the sixth week of pregnancy and reaches its top on 24th weeks and continues to increase until 37th weeks. Iron deficiency anemia begins with depletion of iron deposits (ferritin) and increased absorption iron that described by increasing iron binding capacity. In a further stage of depletion of iron stores, reduced transferrin saturation, reduced amount of protoporpirin which is converted to heme, and will be followed by a decrease in serum ferritin levels. Finally, anemia occurs with its characteristic that is low Hb levels. ${ }^{9}$ Iron deficiency is a result of long-term iron imbalance so that iron reserves in the form of hemosiderin and iron feritin are progressively reduced and no longer meet the need for normal iron adequacy. When the prevalence of iron deficiency anemia reaches $20-30 \%$ in all age groups and sexes, during pregnancy supplementation is recommended as the main strategy and is considered more efironctive and efficient to overcome micronutrient deficiencies (especially iron). Compliance in consuming iron tablets is the compliance of pregnant mother in carrying out the advice of health workers to consume iron tablets according to dosage and drinking schedule. The compliance in this study showed on pregnant mothers' compliance in consuming iron tablets, including the compliance on the number of tablets consumed, how to consume iron tablets and when taking iron tablets. ${ }^{10}$ Pregnant mother who are disobey in consuming iron tablets have a risk of anemia 4,250 times compared to pregnant mother who are complianced in consuming iron tablets. ${ }^{11}$

The standard of ANC service received by pregnant mother is 10T. Examination of hemoglobin levels and administration of iron tablets is part of ANC services. ${ }^{12}$ Completeness of facilities and infrastructure in health facilities should be able to support all prenatal care services needed by pregnant women. Suggestions for ANC visit is minimum $4 \mathrm{x}$ during pregnancy are expected to detect anemia in pregnant mother, so that women with $\mathrm{Hb}$ levels below normal from the start of the pregnancy visit must have received iron tablets. ${ }^{13}$ From $93 \%$ who obey consuming iron tablets, only $53 \%$ of pregnant mother know the benefits. ${ }^{10}$

\section{Materials and Methods}

The design of this study used crosssectional design. This study was conducted on seven Public Health Centre form March

Table 1. Characteristics of research respondents.

\begin{tabular}{|c|c|c|}
\hline Variable & $\mathbf{N}$ & $\%$ \\
\hline $\begin{array}{l}\text { Maternal Age } \\
\quad<20 \text { years } \\
20-35 \text { years } \\
>35 \text { years }\end{array}$ & $\begin{array}{c}4 \\
87 \\
15\end{array}$ & $\begin{array}{r}3.8 \\
82.1 \\
14.2\end{array}$ \\
\hline $\begin{array}{l}\text { Gestational age } \\
\quad \geq 28 \text { weeks ( } 7 \text { months) } \\
\quad \geq 32 \text { weeks ( } 8 \text { months) } \\
\quad \geq 36 \text { weeks ( } 9 \text { months) }\end{array}$ & $\begin{array}{l}35 \\
38 \\
33\end{array}$ & $\begin{array}{l}33 \\
38 \\
31\end{array}$ \\
\hline $\begin{array}{l}\text { Anemia based on pregnancy age } \\
\quad \geq 28 \text { weeks ( } 7 \text { months) } \\
\quad \geq 32 \text { weeks ( } 8 \text { months) } \\
\quad \geq 36 \text { weeks ( } 9 \text { months) }\end{array}$ & $\begin{array}{l}22 \\
18 \\
19\end{array}$ & $\begin{array}{l}37 \\
31 \\
32\end{array}$ \\
\hline $\begin{array}{l}\text { Education } \\
\text { Had no formal education } \\
\text { Elementary } \\
\text { Junior high school } \\
\text { High school } \\
\text { College }\end{array}$ & $\begin{array}{c}5 \\
11 \\
30 \\
40 \\
20\end{array}$ & $\begin{array}{c}4.7 \\
10.4 \\
28.3 \\
37.7 \\
18.9\end{array}$ \\
\hline $\begin{array}{l}\text { Number of Children } \\
\text { New pregnant } \\
\text { 1 person } \\
\text { 2-3 people } \\
\text { 4-5 people }\end{array}$ & $\begin{array}{l}30 \\
34 \\
40 \\
2\end{array}$ & $\begin{array}{c}28.3 \\
32.1 \\
37.7 \\
1.9\end{array}$ \\
\hline $\begin{array}{l}\text { Health Insurance } \\
\text { Yes }\end{array}$ & 106 & 100 \\
\hline $\begin{array}{l}\text { Medical record book } \\
\text { Yes }\end{array}$ & 106 & 100 \\
\hline $\begin{array}{l}\text { Wormy } \\
\quad \text { Negative }\end{array}$ & 106 & 100 \\
\hline
\end{tabular}

Table 2. Frequency distribution.

\begin{tabular}{|c|c|c|c|}
\hline Variable & Measure result & & \\
\hline & & n & $\%$ \\
\hline Anemia & $\begin{array}{l}\text { Anemia } \\
\text { Not Anemia }\end{array}$ & $\begin{array}{l}59 \\
47\end{array}$ & $\begin{array}{l}55.7 \\
44.3\end{array}$ \\
\hline Compliance in consuming Iron tablets & $\begin{array}{l}\text { Disobey } \\
\text { Obey }\end{array}$ & $\begin{array}{l}85 \\
21\end{array}$ & $\begin{array}{l}80.2 \\
19.8\end{array}$ \\
\hline Knowledge of Anemia and Iron tablets & $\begin{array}{l}\text { Less } \\
\text { Good }\end{array}$ & $\begin{array}{l}86 \\
20\end{array}$ & $\begin{array}{l}81.1 \\
18.9\end{array}$ \\
\hline Mothers' attitude in consuming Iron tablets & $\begin{array}{l}\text { Less } \\
\text { Good }\end{array}$ & $\begin{array}{l}64 \\
42\end{array}$ & $\begin{array}{l}60.4 \\
39.6\end{array}$ \\
\hline ANC Sevice $(10 \mathrm{~T})$ & $\begin{array}{l}\text { Below average } \\
\text { Average }\end{array}$ & $\begin{array}{l}89 \\
17\end{array}$ & $\begin{array}{l}84 \\
16\end{array}$ \\
\hline ANC Visit & $\begin{array}{l}\text { Below average } \\
\text { Average }\end{array}$ & $\begin{array}{l}33 \\
73\end{array}$ & $\begin{array}{l}31.1 \\
68.9\end{array}$ \\
\hline Counseling from Health Worker & $\begin{array}{l}\text { No } \\
\text { Yes }\end{array}$ & $\begin{array}{l}58 \\
48\end{array}$ & $\begin{array}{l}54.7 \\
45.3\end{array}$ \\
\hline Pregnant mother class & $\begin{array}{l}\text { No } \\
\text { Yes }\end{array}$ & $\begin{array}{l}81 \\
25\end{array}$ & $\begin{array}{l}76.4 \\
23.6\end{array}$ \\
\hline Available of Iron tablets & $\begin{array}{l}\text { Insufficient } \\
\text { Sufficient }\end{array}$ & $\begin{array}{l}93 \\
13\end{array}$ & $\begin{array}{l}87.7 \\
12.3\end{array}$ \\
\hline Malaria History & $\begin{array}{l}\text { Yes } \\
\text { No }\end{array}$ & $\begin{array}{c}8 \\
98\end{array}$ & $\begin{array}{r}7.5 \\
92.5\end{array}$ \\
\hline Total & & 106 & 100 \\
\hline
\end{tabular}


Agung, Sawah Lebar, Beringin Raya, Lingkar Timur, Nusa Indah, Bentiring and Padang Serai Public Health Center. Sampling taken by puposive sampling technique with 106 respondents.

The data collected with questionnaires include data on characteristics of pregnant mothers, compliance consuming the iron tablets, knowledge of iron tablets, attitudes, health worker counseling, maternal classes and availability iron tablets. Data on ANC visit and ANC services using checklist. Measurement of hemoglobin levels, helminthiasis and malarias were done by laboratory examination.

Univariate analysis was used to see the characteristics of pregnant mothers including age, education, number of children, membership of Jamkesmas, ownership of KIA books and wormy status and variables in this study.

The multivariate analysis that used in the study was used multiple logistic regression test to determine the independent variables were the most dominant influence on the dependent variable in the final modeling. This study has been approved by the Research Ethics Committee from Public Health Faculty of Sriwijaya University.

\section{Results}

Based on the geographical condition of Bengkulu City, it was obtained that all pregnant mothers in this study were able to easily access the nearest health services, and the most did not work, while the rest worked as household helpers (Table 1). Most respondens aged between 20-35 years, gestational age $\geq 32$ weeks ( 8 months), gestational age of anemia was $\geq 28$ weeks ( 7 months) as many as $22(37 \%)$ people. All respondents had health insurance, medical record book and negative worms.

Based on Table 2. it was obtained as many as 59 people $(55.7 \%)$ mothers who suffered from anemia, and only 19.8\% mothers who obeyed consuming iron tablets. $47.2 \%$ mothers had less knowledge about anemia and iron tablets. Most mothers (84\%) received ANC services below average (10T).

Based on Table 3, the results of Chisquare test on factors related to compliance, it was obtained that consumption of iron tablets, ANC services, ANC visits, and availability of iron tablets were significantly relationship with the incidence of anemia (p-value <0.05).

Based on Table 4, the most dominant variable influencing the incidence of iron deficiency anemia was the availability of Iron tablets with a value of $p=0.023$ and
OR 13.995 (95\% CI: 1.438 - 135.459), meaning that the third trimester pregnant mothers who were insufficient of Iron tablets availability had chance 14 times more experiencing in anemia compared to third trimester pregnant mothers who had sufficient the Iron tablets.

\section{Discussion}

The results of multivariate binary logistic regression test showed that compliance in consuming iron tablets was not the dominant factor to influence the incidence of anemia. The results of the study obtained that almost all subjects $(98.9 \%)$ consumed iron tablets, but only $27.5 \%$ obeyed to consume. Pregnant mothers who weren't obedient in consuming iron tablets had a risk of suffering from anemia 4,250 times compared to pregnant mother who were obedient in consuming iron tablet.

Table 3. Relationship between independent and dependent variables.

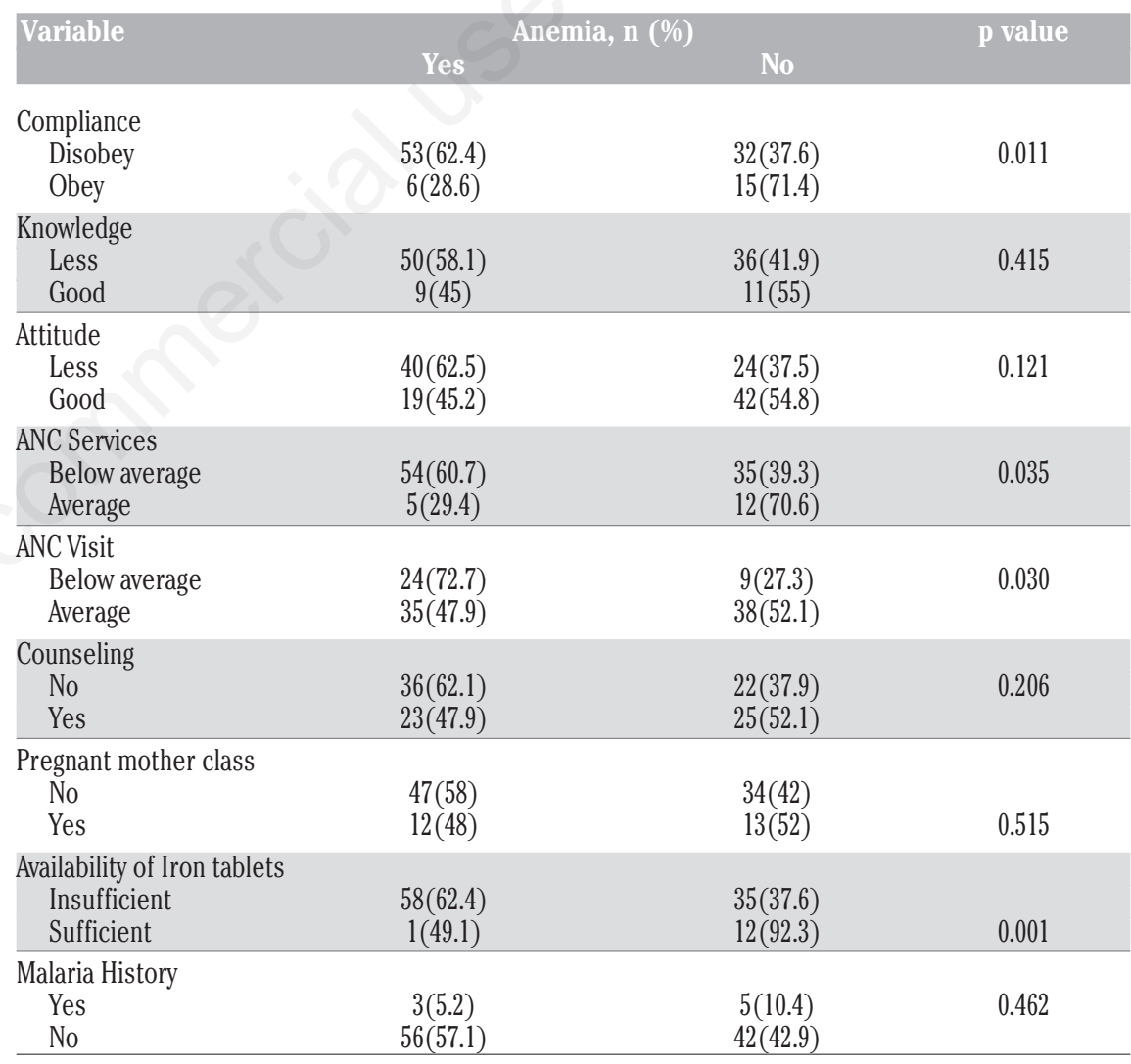

Table 4. Models of Multiple Logistic Regression.

\begin{tabular}{lccc} 
Variable & SE & OR $(95 \% \mathrm{CI})$ & P value \\
Compliance in Consuming the Iron tablets & 0.682 & $1.397(0.367-5.314)$ & 0.624 \\
ANC Service & 0.614 & $3.392(1.018-11.307)$ & 0.047 \\
\hline Availability of Iron tablets & 1.160 & $13.954(1.438-135.459)$ & 0.023 \\
ANC Visits & 0.501 & $1.881(0.705-5.018)$ & 0.207 \\
\hline
\end{tabular}

Bivariate analysis showed there was significant relationship between ANC services with the anemia incidence ( $p$ value $=$ 0.035). Pregnant mothers who received below average ANC services were 3.7 times to experience anemia compared to groups of pregnant mothers who received average ANC services (10T). Multivariate binary logistic regression test showed that ANC services affected the incidence of iron deficiency anemia on pregnant mothers $p$ value $=0.047, \mathrm{OR}=3.40$ (95\% CI: 1.01-11.30), meaning that mothers who received below average ANC services $10 \mathrm{~T}$ was 3.4 times to experience iron deficiency anemia than mothers who received average ANC services (10T). Quality ANC services and accordance to standard were conducted as an effort to detect early risk since the beginning of pregnancy expected to the pregnant mothers and health officers to conduct various activities such as counseling about good nutrition during pregnancy, information on 
the importance of the benefits of consuming Iron tablets, and improving counseling about the harmful efironcts of anemia. ${ }^{14}$ Education and information about the importance of Iron tablets need to be done to the maximumly when pregnant mother get ANC services. Supervision from cadres or health workers in providing iron tablets to pregnant mother in order to consume regularly was very necessary. So the complication cases and even maternal and baby mortality during pregnancy and childbirth can be reduced, one of them through standard ANC services.

There was a significant relationship between the availability of iron tablets and incidence of anemia with ( $p$ value $=0.001$ ) $\mathrm{OR}=8.10$ (95\% CI: 1.26-53.65). It showed that pregnant mother who had insufficient iron tablet had an opportunity of 8.10 times for anemia. Multivariate binary logistic regression test results also showed that iron tablet availability was the dominant factor influencing the incidence of anemia on pregnant mothers $(p$ value $=0.023$ ). Iron consumption $<30$ tablets/month caused anemia on pregnant mothers 3 times compared to pregnant mothers by consumption of Iron tablets $>30$ tablets/month obtained results of pregnant mothers who received/consumed the Iron tablets $<30$ tablets/month had a chance of 2,286 times to suffer from anemia compared to pregnant mothers who consumed Iron tablets $>30$ tablets/month. The health facility that provide the antenatal care is expected to have an estimated need for iron tablets every year so that the supply will be sufficient. The local government began to monitor and evaluate the supply of Iron tablets that should be received by every pregnant mother in an effort to prevent the occurrence of iron deficiency anemia

There was a significant relationship between ANC visits with the incidence of anemia with $(p$ value $=0.03)$ PR: $1.51(95 \%$ CI: 1.10-2.08) meaning that pregnant mothers who had below average ANC visits had 1.5 times chance to experience anemia compared to groups of pregnant mothers who ANC visited was average. Based on the results of multivariate binary regression logistic tests, it showed that ANC visits became confounding variables between compliance to consume of iron tablets with the incidence of iron deficiency anemia. The compliance increasing of pregnant mothers consuming iron tablets on the second visit was $78.48 \%$ and the third visit was $79.13 \% .^{15}$ Preventing the occurance effects of anemia was very important, it is recommended that all pregnant mothers have their $\mathrm{ANC}$ visits regularly.

\section{Conclusions}

The conclusion of the study was that there was a significant relationship among maternal compliance consuming the Iron tablets, ANC services, ANC visits and availability of Iron tablets with the incidence of anemia. The most dominant variable affecting the incidence of anemia was the availability of iron tablets.

\section{References}

1. World Health Organization. The Global Prevalence of Anaemia in 2011. Geneva, World Health Organization; 2015.

2. Walker SP, Wachs TD, Gardner JM, et al. Child development: risk factors for adverse outcomes in developing countries. Lancet 2007;369(9556):145157.

3. World Health Organization. Global Stategy For Women's, Children's and Adolescents' Health (2016-2030). Geneva: World Health Organization; 2015.

4. Sanghvi TG, Harvey PWJ, Wainwright E. Maternal iron-folic acid supplementation programs:Evidence of impact and implementation. Food and Nutrition Bulletin 2010;31(2):S100S107.

5. Flora R, Melvia B, Purwanto S. Profil Zat Besi Ibu Hamil di Daerah Endemis Malaria. Jurnal Kesehatan Masyarakat Nasional 2013;8(5):195-198.

6. Martin SL, Omotoyo MO, Chapleau GM. Adherence partners are an acceptable behaviour change strategy to support calcium and iron-folic acid supplementation among pregnant women in Ethiopia and Kenya. Maternal \& Child Nutrition 2016;13(3):e12331. Available from: https//doi.org/10.1111/mcn.12331. Accessed on: 10 May 2018.

7. Lacerte P, Pradipasen M, Temcharoen P. Determinants of Adherence to Iron/Folate Supplementation During Pregnancy in Two Provinces in Cambodia. Asia Pac J Public Health 2011;23(3):315-323.

8. Kementerian Kesehatan Republik Indonesia. Hasil Riset Kesehatan Dasar 2013. Jakarta: Kemenkes RI; 2013.

9. Wiknjosastro. Ilmu Kebidanan. Jakarta: EGC; 2007.

10. Mbhenyane X, Cherane M. Compliance with the consumption of iron and folate supplements by pregnant women in Mafikeng local municipality, North West province, South Africa. African Health Sciences 2017;17(3):657-670.

11. Fitri YP, Briawan D, Tanziha I, et al. Kepatuhan Konsumsi Tablet Iron dan Pengaruhnya Terhadap Kejadian Anemia Pada Ibu Hamil. Jurnal Gizi Pangan 2015;10(3):171-178.

12. Kementerian Kesehatan Republik Indonesia. Pedoman Pelayanan Antenatal Terpadu. Jakarta: Direktorat Jenderal Bina Gizi dan Kesehatan Ibu dan Anak; 2012.

13. Nanda DD, Rodiani. Hubungan Kunjungan Antenatal Care dengan Kejadian Anemia pada Ibu Hamil Trimester III. Majority 2017;7(1):8893.

14. Gebremedhin S, Samuel A, Mamo G. Coverage, compliance and factors associated with utilization of iron supplementation during pregnancy in eight rural districts of Ethiopia: a crosssectional study. BMC Public Health 2014;14(607):1-8.

15. Bilimale A, Anjum J, Sangolli HN, et al.. Improving Adherence to Oral Iron Supplementation during pregnancy. Australasian Medical Journal 2010;3(5):281-290. 